\title{
Mortality incident in northern bald ibis Geronticus eremita in Morocco in May 1996
}

\author{
Jamal Touti, Fatima Oumellouk, Christopher G. R. Bowden, James K. Kirkwood and Ken W. Smith
}

\begin{abstract}
In May 1996 there was an acute and dramatic mortality incident in the last remaining wild population of northern bald ibis Geronticus eremita. This species is Critically Endangered, comprising only about 250 wild individuals, which occur on the Atlantic coast of southern Morocco. Over a period of 10 days a total of 38 adult birds (aged 1 year or more) died or disappeared. Deaths, probably secondary to the loss of one or both parent birds, also occurred subsequently in six
\end{abstract}

estlings and one recent fledgling. The incident appeared to involve no other species. This paper describes the pattern of the incident, and pathological, microbiological and toxicological investigations and findings. Several features point to a toxic aetiology but the cause of the incident has not been established.

Keywords Bald ibis Geronticus eremita, epidemic, freeliving population, mortality incident.

\section{Introduction}

Following a dramatic decline in population size and range during recent centuries (Cramp \& Simmons, 1977; Collar \& Stuart, 1985), the northern bald (or waldrapp) ibis Geronticus eremita is known to breed at only two coastal sites near Agadir in Morocco (Brindley et al., 1995). The ibis became extinct in Europe during the seventeenth century and residual populations elsewhere in Morocco, Algeria, Yemen and Turkey have apparently died out in recent years. The species is Critically Endangered with a total remaining wild population of approximately 250 (IUCN, 1996). A further c. 2000 birds, mainly of Moroccan origin, are maintained in zoos (Tomlinson, 1994; V. Hirsch, pers. comm.) but, so far, attempts to reintroduce captive birds into the wild have been unsuccessful. The causes of the historical decline in the wild populations are not entirely clear but environmental pollution with persistent organochlorine pesticides may have played a role during the third quarter of the present century. Hunting, human disturbances at breeding sites and loss of

Jamal Touti, Fatima Oumellouk Laboratoire D'Analyses et Récherches Vétérinaire d'Agadir, Agadir, Morocco.

Chris Bowden, Ken Smith Conservation Science Department, Royal Society for the Protection of Birds, The Lodge, Sandy, Bedfordshire SG19 2DL, UK.

James K. Kirkwood (corresponding author) Institute of Zoology, Regent's Park, London NW1 4RY, UK. Present address: Universities Federation for Animal Welfare, The Old School, Brewhouse Hill, Wheathampstead, Hertfordshire AL4 8AN, UK.

E-mail: kirkwood@ufaw.org.uk

Received 27 July 1998. Accepted 3 November 1998 feeding habitat are thought also to have been significant contributing factors (Collar \& Stuart, 1985).

The bald ibis breeds at two places: one about $50 \mathrm{~km}$ north of Agadir and the other about the same distance to the south of Agadir in the Souss-Massa National Park. At the southern location, there are nests at three sites (A, B, and C) within a few kilometres of each other. Their precise location is not publicized to help avoid potential disturbance by visitors. The birds nest on ledges on inaccessible sea cliffs, and forage mainly in uncultivated steppe areas and fields near the coast.

During the breeding season in May 1996 an acute mortality incident occurred, involving birds from the nesting sites $B$ and $C$. Over a period of 10 days a total of 38 adult birds (aged 1 year or more) died or disappeared from these sites. Deaths, probably secondary to the deaths of adult (parent) birds, also occurred in six nestlings and one recent fledgling. The incident appeared to involve no other species. Here we describe the pattern of the incident and discuss its possible causes.

\section{History and pattern of the incident}

On 9 May 1996, a warden noticed a sick subadult ibis at breeding site C. This bird (No. 2 in Table 1) died the following day but the carcass could not be immediately retrieved because of difficulties of access. During the following days, a further 20 adult birds (aged 1 year or more) died and 17 others disappeared and were assumed to have died. One recent fledgling and six nestlings also died. Details of sex, age, weight, date (or estimated date) and place of death of the total of 28 birds whose deaths were observed or whose carcasses 
Table 1 Details of birds observed to die or found dead in the 1996 bald ibis mortality incident

\begin{tabular}{|c|c|c|c|c|c|c|c|}
\hline \multirow[b]{2}{*}{ No. } & \multirow[b]{2}{*}{ Sex } & \multirow{2}{*}{$\begin{array}{l}\text { Age } \\
\text { (years) }\end{array}$} & \multirow{2}{*}{$\begin{array}{l}\text { Weight } \\
(\mathrm{kg})\end{array}$} & \multicolumn{2}{|c|}{ Dates (May 1996) of: } & \multirow[b]{2}{*}{ Site } & \multirow[b]{2}{*}{ Notes } \\
\hline & & & & death* & retrieval/observation & & \\
\hline 1 & & $3+$ & 1.10 & 12 & 13 & $\mathrm{C}$ & \\
\hline 2 & & 2 & 0.92 & 10 & 13 & $\mathrm{C}$ & \\
\hline 3 & & $3+$ & 1.28 & 12 & 13 & $\mathrm{C}$ & \\
\hline 4 & & $\mathrm{~N}$ & 0.66 & 13 & 13 & C & \\
\hline 5 & & $3+$ & 1.04 & 12 & 13 & C & \\
\hline 6 & $\mathrm{M}$ & $3+$ & 1.10 & 12 & 13 & $\mathrm{C}$ & \\
\hline 7 & $\mathrm{~F}$ & $3+$ & 0.90 & $<14^{*}$ & 14 & SM & dead by lagoon \\
\hline 8 & & $3+$ & 1.13 & $<14^{*}$ & 14 & $\mathrm{SM}$ & dead in lagoon \\
\hline 9 & & $3+$ & 1.22 & $<14^{*}$ & 14 & SM & dead in lagoon \\
\hline 10 & $\mathrm{~F}$ & $3+$ & 1.16 & $<14^{*}$ & 14 & $\mathrm{SM}$ & dead in lagoon \\
\hline 11 & & $3+$ & 1.3 & $<14^{*}$ & 14 & SM & dead in lagoon \\
\hline 12 & & $\mathrm{~N}$ & 0.64 & 15 & 16 & $\mathrm{C}$ & following parents' deaths \\
\hline 13 & $\mathrm{~F}$ & $3+$ & 0.99 & 16 & 16 & C & \\
\hline 14 & & 1 & 0.98 & 16 & 16 & SM & seen ill before death near lagoon \\
\hline 15 & & 1 & 0.89 & 15 & 16 & SM & near lagoon \\
\hline 16 & & $3+$ & 1.06 & 16 & 16 & SM & \\
\hline 17 & & $2+$ & & $<14^{*}$ & 17 & SM & \\
\hline 18 & & $2+$ & & $<14^{*}$ & 15 & SM & $\begin{array}{l}\text { carcass eaten by dog } 1.5 \mathrm{~km} \mathrm{~S} \text { of } \\
\text { lagoon }\end{array}$ \\
\hline 19 & & $2+$ & & $<14^{*}$ & 15 & SM & $2 \mathrm{~km} \mathrm{NE}$ of lagoon \\
\hline 20 & & $2+$ & & 13 & - & $\mathrm{C}$ & \\
\hline 21 & $\mathrm{M}$ & $3+$ & 1.15 & 18 & 20 & At & seen ill before death \\
\hline 22 & & $\mathrm{~N}$ & 0.64 & 19 & 20 & C & \\
\hline 23 & $\mathrm{~F}$ & $2 / 3$ & 1.06 & 19 & 20 & $\mathrm{C}$ & \\
\hline 24 & & $\mathrm{~N}$ & 0.61 & 23 & 24 & C & \\
\hline 25 & & $\mathrm{~J}$ & & 28 & 28 & $\mathrm{SM}$ & seen ill before death \\
\hline 26 & & $2+$ & & 13 & 29 & $\mathrm{SM}$ & \\
\hline 27 & & $\mathrm{~N}$ & & 27 & 29 & $\mathrm{C}$ & into the sea \\
\hline 28 & & $\mathrm{~N}$ & & 28 & 29 & $\mathrm{C}$ & into the sea \\
\hline
\end{tabular}

$\mathrm{N}$, nestling; J, recently fledged juvenile; $\mathrm{C}$, breeding site $\mathrm{C}$; B, breeding site B; SM, at or near the lagoon at Sidi Moussa.

* Dates of death are known to be accurate to within 1 day unless, where marked with an asterisk, dates of death have been estimated from state of carcass.

† This bird (No. 21), although found dead at site A was known from the pigmentation pattern of its head to be from site B.

were seen are listed in Table 1 . Of these 28 birds, 21 were retrieved for examination.

The deaths occurred over a short period, with most of the deaths of adult birds occurring within the first 5 days of the start of the incident (Fig. 1). Most of the deaths of the young birds (fledgling and nestlings) occurred at relatively later stages (Fig. 1) suggesting that these deaths may have been related, at least in part, to loss of one or both parents (this was certainly the case for nestling No. 12).

Birds were found dead at or near one of three sites (Table 1). Fourteen died at breeding site C, 13 at or near a brackish lagoon by the village of Sidi Moussa, and one at breeding site A. However, the bird (No. 21) that died at site $A$ was known from the characteristic pigmentation pattern of its head to be a breeding adult from site $B$. All the deaths occurred in birds from sites $B$ and $C$ and it appeared that birds at site $A$ were unaffected. Although birds from site B disappeared, no deaths or carcasses were observed at that site. This may be because it is very likely that ill birds here would have fallen directly into the sea.

Most of the birds that died at site $C$ fell on to the rocks below the nesting ledges and the carcasses were retrieved by descending the cliffs. Two of the site $\mathrm{C}$ nestlings (Nos 27 and 28) died by drowning on falling into the sea. It had been noted by the wardens watching this site that the chicks had not been fed (their parents had presumably died) and they were seen to glide down into the sea well before they were able to fly; it is assumed that this was a result of terminal disease or weakness. Of the birds that were found dead at Sidi Moussa on 14 May, one was found on the shore at a small cove on the north side of the lagoon and four were found in the adjacent water. The lagoon was periodically used as a resting/preening site for the 
birds, both prior to the incident and subsequently. Over the following 3 days, five others died near this lagoon (being found at various distances up to $2 \mathrm{~km}$ from it). The birds were at this time mainly feeding in the open steppe and around sparse sandy barley fields, some of which had been harvested during the previous week.

During this incident, the only other avian deaths noted were of a fledged juvenile lanner falcon Falco biarmicus on the cliff ledges at site $C$ and of an adult shag Phalacrocorax aristotelis, also at site $\mathrm{C}$. The lanner falcon could not be retrieved for examination but the shag was found to have died of a cloacal impaction. There is no evidence that these deaths were linked to the ibis incident and there was no indication of unusual mortality in any other species. Few other birds occur in the area but up to 25 lesser black-backed gulls Larus fuscus were frequenting the opposite end of the lagoon at the time and these were apparently unaffected.

The population at sites $\mathrm{B}$ and $\mathrm{C}$ prior to the incident comprised 50 pairs of adult ( $>1$ year) birds, 20 nonbreeders and 61 nestlings. There were a further seven pairs at nearby site $A$. Counts made at the breeding sites prior to and after the mortality incident suggested that there were 38 fewer adults present after the incident (site $\mathrm{A}$ birds were unaffected). It seems likely that in addition to the 21 known deaths in adults a further 17 had occurred. The overall percentage mortality in birds aged $>1$ year at the sites affected was thus 32 per cent (38/120) and it appeared that the incident also lead to the deaths of about 11 per cent $(7 / 61)$ of the chicks at these sites.

The ages of the 21 birds aged 1 year or over retrieved for post-mortem examination were estimated from the extent of feathering on the head. Three were 1-year-old birds with numerous feathers on their heads, and two (Nos 2 and 23) were thought to be 2-3 years old on the

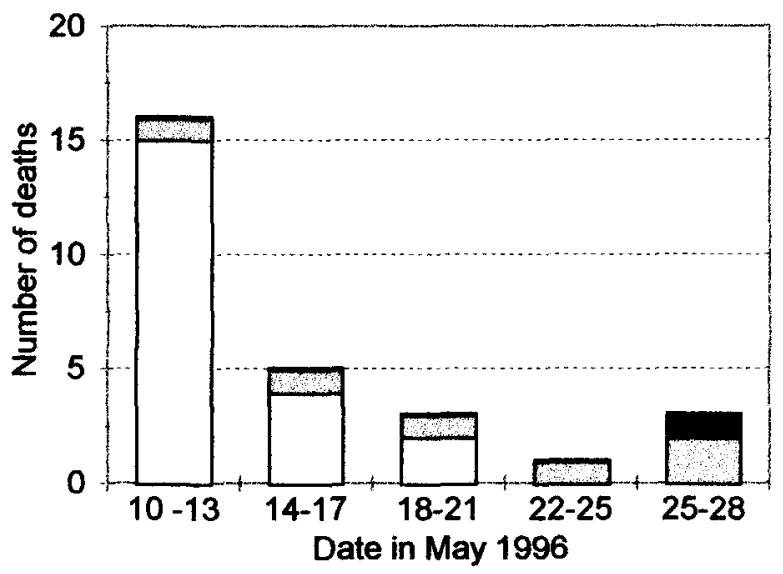

Fig. 1 Temporal distribution of deaths during the bald ibis mortality incident in Morocco, May 1996. White, birds aged 1 year and over; grey, nestlings; black, recently fledged. basis of their adult appearance, immature gonads and the presence of few cheek feathers. Eleven were thought to be $\geq 3$ years old and the remaining five birds were too decomposed for precise ageing, but were at least in their second year. Thus incidence rates, among the birds whose carcasses were retrieved, appeared to be approximately 10 per cent $(12 / 120)$ breeding birds and 25 percent $(5 / 20)$ non-breeders (subadults). Further evidence that a higher proportion of non-breeders than breeders was affected derived from the observation that of seven first-year birds that regularly roosted at site $C$, only one was seen subsequent to the incident.

\section{Clinical signs}

Most of the birds (22 out of the 28 whose place of death was known) were found dead. Of the other six, three (Nos 25, 27 and 28) were dependent young whose deaths may have been a sequel to the loss of one or both parents. Of these, nestlings Nos 27 and 28 were those that drowned in the sea (see above), No. 25 had fledged and was reported by a local man to have been seen walking, showing signs of incoordination, into the lake. This man caught the bird but it died soon afterwards en route for the Veterinary Laboratory at Agadir. The adult from site B, which was retrieved from site A, was seen to die there as a result of flying into the sea cliff. The only other bird seen alive prior to death was No. 14. This was reported to have shown signs of incoordination and weakness shortly before it died overnight near the lagoon at Sidi Moussa. The finding of some material, which appeared to have been regurgitated at the ibis resting place beside the lagoon at Sidi Moussa, suggested that at least one of the affected birds may have regurgitated before death.

\section{Post-mortem findings}

The carcasses or remains of carcasses of 21 birds aged 1 year or older and seven hatched in 1996 were seen and, of these, carcasses of 18 1-year-old, or older, birds and five 1996-hatched birds (four nestlings and the fledgling) were retrieved for post-mortem examinations. The others were irretrievable, incomplete or very decomposed.

\section{Gross pathology}

Most of the carcasses were in a very advanced state of decomposition at time of examination because of the difficulties of finding, retrieval and transport to the laboratory in Agadir, combined with the high ambient temperature. However, some were reasonably fresh. 
The adult birds examined were in good body condition and body weights (ranging from 0.9 to $1.28 \mathrm{~kg}$ ) were within the expected normal weight range: the mean adult value being about $1.1 \mathrm{~kg}$ (Cramp \& Simmons, 1977). Several birds (e.g. No. 18) were noted to have rather fluid yellow gizzard and gut contents, and brown fluid poured from the beak of No. 23 during preliminary external examination. Small focal haemorrhages were seen on the surface of the liver of birds Nos 7 and 14, and pinpoint white foci were noted on the surface of the livers of birds Nos 13 and 14. Traces of urates were observed on the kidneys of bird No. 19. Feather lice were noted on the young birds and intestinal parasites, including cestodes, were observed in some, but in no case was the parasite burden considered to be of clinical significance. Some birds had food in their upper digestive tracts, others did not. It was noted that No. 25 had a full stomach. The stomach contents were a mixture of mainly Acanthadactylus lizards, small tenebrionid beetles and some snails. In one case there were a few grains of barley, but otherwise the contents appeared to be typical and consistent with findings from faecal analyses in other years (Bowden \& Smith, 1997).

\section{Histopathology}

A range of tissues including liver, intestine and kidney from birds Nos $7,12,13,14$ and 23 were examined by light microscopy. No significant lesions were observed but the tissues were in an advanced state of autolysis.

\section{Bacteriology}

Samples were taken for bacteriology from a range of tissues including lung, liver, intestine, heart, bone marrow, spleen and brain. No significant aerobic bacteria were cultured. A Clostridium sp., not Clostridium botulinum, was isolated but it seems unlikely that this was a significant finding in view of the decomposition of the carcasses (there was no evidence to support a diagnosis of botulism-see below).

\section{Virology}

Virological examinations were carried out at the Laboratoire Régionale d'Analyses et Récherches Vétérinaire d'Agadir and at the Biopharma Laboratory in Rabat. Samples of lung, trachea, liver, spleen and kidney from birds $\operatorname{Nos} 7,12,13,14$ and 23 were analysed. Samples of lung, trachea, liver and kidney from these birds were also screened for pathogenic viruses at the Avian Virology Laboratory at the Central Veterinary Laboratory in the UK. Material was passaged (repeatedly cultured) on embryonated eggs and on tissue cultures but no virus was isolated.

\section{Toxicology}

\section{Botulinum toxin}

In an initial bioassay for botulinum toxin carried out at the Laboratoire Régionale d'Analyses et Récherches Vétérinaire d'Agadir, one out of five mice injected with a sample prepared from stomach contents died. In a second test at this laboratory, five mice each were injected with samples prepared from kidneys, liver and blood. Two of those injected with blood died after $24 \mathrm{~h}$. In a last assay, none of six mice inoculated with liver and blood samples from Nos 10 and 23 died. Gizzard samples from birds Nos 13, 14 and 25 were also examined for botulinum toxin by bioassay at the Department of Bacteriology at the Central Veterinary Laboratory and were found to be negative.

\section{Pesticides}

Samples of liver, kidney and stomach contents from all birds from which these materials were available were pooled and screened at the Laboratoire Régionale d'Analyses et Récherches Vétérinaire de Casablanca for organochlorines, organophosphates and pyrethroids. In addition, samples of liver and kidney from birds 3, 4, 20 and 26 were screened for anticoagulants. All analyses were negative. Samples of stomach contents, heart muscle, intestine, brain and liver from Nos 12, 13 and 14 were sent to the Central Science Laboratory, UK, for screening for pesticides (Brown et al., 1996). No significant levels of organochlorines, organophosphates, molluscicides (metaldehyde and carbamates), other carbamates, strychnine or chloralose (alpha or beta) were found in these samples.

\section{Phytoplankton toxins}

A water sample collected on 22 May from the water's edge at the cove of the lagoon at Sidi Moussa, at which several birds had been found dead the previous week, was sent for examination for potentially harmful algae to the Department of Biological Sciences, University of Dundee. This sample was found to contain a wide variety of fresh/brackish water phytoplankton including, in low numbers, Merismopedia and Synechococcus species and larger numbers of the filamentous bluegreen algae Oscillatoria limnetica and other Oscillatoria spp. These organisms have the potential to produce a range of toxins but because of their relative scarcity in the sample examined it was not considered likely that they represented an acute poisoning hazard. However, the sample was collected 12 days after the main mortality occurred and it is known that algal blooms can be 
transient and short-lived. Crop samples were not available for examination, but no potentially harmful toxinproducing phytoplankton were apparent in gizzard samples from three birds (Nos 13, 14 and 25). The regular monitoring programme undertaken by the Moroccan state veterinary services for dinoflagellate toxins (those causing paralytic shellfish poisoning and diarrhoeic shellfish poisoning) in shellfish collected along the shores between Agadir and Tiznit revealed no presence of these toxins before or during the bald ibis mortality incident.

\section{Discussion}

Acute mortality incidents in birds can be caused by a variety of infectious or non-infectious agents, by food shortage or by extreme climatic conditions (e.g. Underwood \& Stowe, 1984; Cunningham \& Simmonds, 1992). Very little is known of specific disease susceptibilities of the bald ibis but among the infections that are known to cause mortality incidents in some avian taxa are a range of virus diseases (Ritchie \& Carter, 1996) including, for example, Newcastle (a paramyxovirus) disease (Alexander, 1991) and avian influenza (Becker, 1966); bacterial diseases such as salmonellosis and pasteurellosis (Friend, 1987); chlamydiosis (Franson \& Pearson, 1995); and a variety of parasitic infestations, for example of acanthocephala in waterfowl (Rayski \& Garden, 1961). Among toxic diseases that have caused avian mortality incidents are botulism (Lloyd et al., 1976; Locke \& Friend, 1987; Wobeser, 1997), accidental or deliberate poisonings with a variety of types of pesticides (e.g. Augsperger et al., 1996; Fletcher et al., 1996) or other environmental pollutants (e.g. lead; Mateo et al., 1997), and poisonings caused by toxins produced by algal or dinoflagellate blooms (Codd \& Poon, 1988; Beasley et al., 1989; Work et al., 1993). In this case the cause of the incident was not established but some of the possibilities listed above can be excluded.

This incident was characterized by a sudden onset and relatively short duration. It appeared that the disease was acute and led rapidly to the death of affected birds while they were in good body condition and while some still had food in their upper digestive tracts. No birds were available for clinical examination prior to death and the clinical signs reported (incoordination, apparently rapid progress to death, and possibly regurgitation) could have been due to a variety of diseases and were of little help with diagnosis. With the exception of one at breeding site $A$, all the known deaths occurred at one of two sites: at or near the lagoon at Sidi Moussa or at breeding site $C$ (Table 1). Only birds from breeding sites $B$ and $C$ were involved although the death of a bird from site $B$ at site $A$ suggested that movements between the sites occurred. Data on foraging behaviour collected prior to the incident showed that the birds from site $A$ were feeding in different areas from the birds at sites B and $\mathrm{C}$. The site $\mathrm{A}$ birds were foraging about $10 \mathrm{~km}$ to the north in the Souss-Massa National Park and those at B and $C$ were foraging approximately $12 \mathrm{~km}$ in the opposite direction in the south of the park. The majority of the adult birds whose dates of death were known or could be reasonably accurately estimated died within the first 5 days but the death of the fledgling and most of the deaths of the nestlings occurred relatively later (Fig. 1).

There had been no dramatic meteorological events that could have caused the deaths, and clearly the birds had not died of food shortage. It should be noted, however, that the rainfall over the previous winter (the average for four stations in the Massa region was $385 \mathrm{~mm}$ ) was approximately double the average and followed a series of unusually dry years. It had rained a few days prior to the incident. Several features make it unlikely that the incident was caused by an infectious agent. First, although initially, with the observation of a death in a lanner falcon and a shag, it appeared that a number of species might be involved, these two deaths were almost certainly coincidental and there is no evidence that any species other than bald ibis were involved (at least some of the possible infectious agents listed above might also have caused mortality in other species). Second, the temporal and spatial patterns of the deaths was not suggestive of the spread of a contagious agent through the colonies. Most birds appeared completely unaffected. Those that were involved were all from breeding sites $B$ and $C$, although the presence of the affected bird from site B at site A might have provided a route for spread of a virulent infection, had this been the case, to site A. Overall chick mortality exceeded that in 1995 by only 11 (60 fledged 1995 and 49 in 1996; Bowden \& Smith, 1997). Thus there were relatively few deaths in chicks and these, occurring in the days following the initial deaths in adults, were consistent with death due to loss of one or both parents. Third, with the exception of the pinpoint focal lesions observed on the livers of two birds (whose significance we have been unable to ascertain), post-mortem findings did not suggest an infectious cause of death. Finally, and most crucially, no pathogens were detected in bacteriological and virological examinations. At about the same time as the mortality incident in bald ibis, cases of West Nile Fever were diagnosed in horses in the north and south-west of Morocco, which were attributed to the spread of infection from wild migrating birds. This virus disease is not known to be a cause of acute mortality incidents in wild birds and for this reason, and others outlined above, it was thought unlikely to have been the cause of the ibis incident. 
The very acute and brief nature of the incident and the fact that only birds that foraged in the southern part of the park were involved strongly suggests that it may have been due to ingestion of a poison at a foraging site. A higher proportion of non-breeders than breeders was affected and this would be consistent with a difference in exposure related to the observed difference in habits-non-breeders spent more time at the lagoon at Sidi Moussa than breeders. Several possible toxicities were considered. First, the deaths might have been due to botulism, which is a common cause of mortality in birds that forage in or beside fresh or brackish water lakes, especially when warm conditions favour the growth and toxin production of Clostridium botulinum Type $\mathrm{C}$ in rotting carcasses. Second, the incident could have been caused by the accidental or deliberate poisoning by pesticides or other toxic agents because the birds forage in areas that included some cultivation. Third, the birds could have ingested prey items or water containing a toxin resulting from an algal bloom at the lagoon at Sidi Moussa.

Regarding the possibility of botulism, the pattern of the epidemic, the clinical signs and the normal appearance of the tissues at post-mortem examination were consistent with botulism. It is conceivable that the birds could, for example, have ingested maggots containing botulinum toxin from a carcass on the shore of the lagoon at Sidi Moussa, or at a nearby foraging area, and that some had died at the lagoon but others had been able to fly back to the breeding site before absorbing incapacitating or lethal doses. However, against this, it might have been expected that if the incident were due to botulism, carcasses of gulls or other waterbirds might have been found at the lagoon at Sidi Moussa, but none was. Thorough searches were made around the drinking pool immediately after the incident for any potentially contaminated food sources. While there were (as usual) small amounts of domestic rubbish, nothing unusual was found. Very few people inhabit the feeding areas. Questioning at the nearest three small settlements revealed no indication of mortality in domestic fowl or other animals. The area over which the ibis forage is large and the possibility of some maggot-infested carcass of a domestic (e.g. sheep or goat-see below) or other animal being present but undetected cannot be ruled out. Unfortunately, no attempt was made to culture Clostridium botulinum from stomach samples but bioassays of stomach contents and tissues for botulinum toxin did not support a diagnosis of botulism. Nevertheless, botulism cannot be entirely discounted. Although some of the samples examined were collected from relatively fresh carcasses, it is possible that the toxin could have been broken down in the interval between death and their collection for analysis.

The areas where the birds were feeding during the week prior to the incident are primarily uncultivated steppe on a very sandy substrate. This is unintensively grazed by sheep and goats throughout the year. Less than 25 per cent of these areas is cultivated; barley was being harvested by hand and several fields contained corn stacks at the time of the incident. This raised the question as to whether any rodent-control measures might have been used, which could have caused the incident. However, local people questioned indicated that rodent-control agents were not used (and that the cost of doing so would be prohibitive). There was an indication that foxes were being trapped in the area and it is possible that, if so, poisons might also have been being used. The results of pesticide analyses showed that no significant residues of widely used compounds were detected from the tissues. The methods used for these analyses were sensitive and reliable, and proven in similar types of incident. Although the freshness of the carcasses and conditions of retaining the samples were not exactly known, analytical results from comparable incidents would suggest that poisoning by compounds containing organochlorines, organophosphates, carbamates, metaldehyde, strychnine, anticoagulant agents (such as warfarin) or chloralose was unlikely in this incident.

A number of species of phytoplankton (blue-green algae, diatoms) can produce toxins lethal to vertebrates (Beasley et al., 1989; Work et al., 1993). Disease or mortality can occur either through drinking water that contains high concentrations of the toxin or through ingesting invertebrates in which the toxin has been accumulated (Codd \& Bell, 1996). The mode of action of these phytoplankton toxins varies: some cause acute mortality through direct action on the nervous system and others cause severe liver damage leading to death after a few days. Toxic algal blooms can be transient and short-lived and, although there was no evidence for an algal bloom either on inspection of the lagoon or analysis of a water sample collected from it on 20 May, no potentially harmful toxin-producing organisms were found in gizzard samples examined, and the shellfish monitoring programme had revealed no evidence of dinoflagellate toxins, the possibility that the deaths were caused by a neuro-active phytoplankton toxin cannot be discounted entirely. For the same reasons, and in view of the very acute nature of the incident and the good body condition of the birds, it is considered very unlikely that hepato-toxic phytoplankton toxins were the cause. 
Mortality incidents have occurred in wild birds as a result of ingestion of alcohol in fermenting fruit. Tissue alcohol levels were not measured but alcohol poisoning is thought very unlikely to have been the cause because the birds appear to eat fruit rarely, there was no evidence of recent ingestion of berries or other fruit at post-mortem, and no abundant sources of fruit were apparent in the area.

To conclude, although we have been able to rule out a number of the possible causes of this dramatic and acute mortality incident in northern bald ibis, the diagnosis remains open.

\section{Acknowledgements}

We are most grateful to the Administration des Eaux et Forêts et de la Conservation des Sols, and in particular to their staff at the Souss-Massa National Park, the Park Director Mohamed Ribi as well as Ali Aghnaj and Alaoui Boubker, to Dr Dennis Alexander, $\mathrm{Mr}$ Dick Gough and staff of the Avian Virology Department of the MAFF Central Veterinary Laboratory for virological analyses, Dr Mark Fletcher, Ms Libbie Barnett and staff of the Wildlife Incident Unit, MAFF Central Science Laboratory for advice and pesticide analyses, Professor Geoffrey Codd, University of Dundee, for advice on algal agents and examination of water samples, Mr Neil Palmer of the Bacteriology Department of the MAFF Central Veterinary Laboratory for examination of stomach contents for botulinum toxin, Drs $\mathrm{H}$. Fox and $\mathrm{H}$. Moore of the University of Derby for other water analyses, to Mohamed El Gadrouri and Lahsen Aguerten for help to retrieve carcasses, and to the Office Régional de Mise en Valeur Agricole Souss-Massa, Agadir, for meteorological data. We also thank Drs Ian Keymer and Nigel Collar for helpful comments on a previous draft of this paper.

\section{References}

Alexander, D.J. (1991) Newcastle disease and paramyxovirus infections. In Diseases of Poultry, 9th edn. (eds B. W. Calnek, H. J. Barnes, C. W. Beard, W. M. Reid and H. W. Yoder), pp. 496-519. Iowa State University Press, Ames, Iowa.

Augsperger, T., Smith, M.R., Meteyer, C.U. \& Converse, K.A. (1996) Mortality of passerines adjacent to a North Carolina corn field treated with granular carbofuran. Journal of Wildlife Diseases, 32, 113-116.

Beasley, V.R., Cook, W.O., Dahlem, A.M., Hooser, S.B.,
Lovell, R.A. \& Valentine, W.M. (1989) Algae intoxication in livestock and waterfowl. Clinical Toxicology, 5, 345-361.

Becker, W.B. (1966) The isolation and classification of Tern virus: Influenza Virus A/Tern/South Africa/1961. Journal of Hygiene, Cambridge, 64, 309-320.

Bowden, C.G.R \& Smith, K. (1997) Conservation of the bald ibis in the Souss-Massa National Park. Royal Society for the Protection of Birds, Sandy, Bedfordshire.

Brindley, E., Dimmick, C., Bowden, C., Ribi, M., Hoffmann, D. \& del Nevo, A. (1995) The bald ibis: a species on the brink? RSPB Conservation Review, 9, 76-79.

Brown, P., Charlton, A., Cuthbert, M., Barnett, L., Ross, L., Green, M., Gillies, L., Shaw, K. \& Fletcher, M. (1996) Identification of pesticide poisoning in wildlife. Journal of Chromatography, A754, 463-478.

Codd, G.A. \& Poon, G.K. (1988) Cyanobacterial toxins. In Biochemistry of the Algae and Cyanobacteria (eds J. G. Gallon and L. J. Rogers), pp. 283-296. Clarendon Press, Oxford.

Codd, G.A. \& Bell, S.G. (1996) The Occurrence of Blue-green Algal Toxins in Freshwaters. National Rivers Authority Research and Development Report No. 29, pp. 30. HMSO, London.

Collar, N.J. \& Stuart, S.N. (1985) Northern bald ibis Geronticus eremita (Linnaeus 1758). In The ICBP/IUCN Red Data Book. International Council for Bird Preservation and International Union for the Conservation of Nature, Cambridge, UK, and Gland, Switzerland.

Cramp, S. \& Simmons, K.E.L. (eds) (1977) Handbook of Birds of Europe, the Middle East and North Africa: the Birds of the Western Palearctic. 1: Ostrich to Ducks. Oxford University Press, Oxford.

Cunningham, A.A. \& Simmonds, M. (1992) Unusual mass mortality of juvenile kittiwakes (Rissa tridactyla) Veterinary Record, 130, 448-449.

Fletcher, M.R., Hunter, K., Barnett, E.A. \& Sharp, E.A. (1996) Pesticide Poisoning of Animals 1995: Investigations of Suspected Incidents in the United Kingdom. MAFF Publications, London.

Franson, J.C. \& Pearson, J.E. (1995) Probable epizootic chlamydiosis in wild California (Larus californiacus) and ring-billed (Larus delawarensis) gulls in North Dakota. Journal of Wildlife Diseases, 31, 424-427.

Friend, M. (1987) Avian cholera. In Grainer, E.C. \& Baxter, W.L. (1974) A localised epizootic of trichomoniasis in mourning doves. Journal of Wildlife Diseases, 10, 104-106.

IUCN (1996) 1996 IUCN Red List of Threatened Animals. IUCN, Gland, Switzerland.

Lloyd, C.S., Thomas, G.J., MacDonald, J.W., Borland, E.D., Standring, K. \& Smart, J.L. (1976) Wild bird mortality caused by botulism in Britain, 1975. Biological Conservation, 10, 119-129.

Locke, L.N. \& Friend, M. (1987) Avian botulism. In Field Guide to Wildlife Diseases (ed. M. Friend), pp. 83-93. United States Department of the Interior Fish and Wildlife Service. Resource Publication 167.

Mateo, R., Dolz, J.C., Aguilar Serrano, J.M., Belliure, J. \& Guitart, R. (1997) An epizootic of lead poisoning in greater flamingos (Phoenicopterus ruber roseus) in Spain. Journal of Wildife Diseases, 33, 131-134. 
Rayski, C. \& Garden, E.A. (1961) Life-cycle of an acanthocephalan parasite of the eider duck. Nature, 192, 185-196.

Ritchie, B.W. \& Carter, K. (1996) Avian Viruses: Function and Control. Wingers Publishing Inc, Lake Worth.

Tomlinson, C. (1994) A review of red-cheeked ibis or Waldrapp Geronticus eremita conservation. International Zoo Yearbook, 33, 67-73.

Underwood, L.A. \& Stowe, T.J. (1984) Massive wreck of seabirds in eastern Britain, 1983. Bird Study, 31, 79-88.

Wobeser, G. (1997) Avian botulism-another perspective. Journal of Wildlife Diseases, 33, 181-186.

Work, T.M., Barr, B., Beale, A.M., Fritz, L., Quilliam, M.A. \& Wright, J.L.C. (1993) Epidemiology of domoic acid poisoning in brown pelicans (Pelecanus occidentalis) and Brandt's cormorants (Phalacrocorax penicillatus) in California. Journal of Zoo and Wildlife Medicine, 24, 54-62.

\section{Biosketches}

James Kirkwood is interested in diagnosis of and responses to wildlife diseases and especially in anthropogenic impacts on free-living wild animals at both population (conservation) and individual (welfare) levels.

Jamal Touti is mainly involved in laboratory veterinary diagnostics of farm animal diseases affecting wild and reintroduced species including bald ibis, addax and ostrich.

Chris Bowden coordinates the research programme for bald ibis, based within the Souss-Massa National Park. This involves field data collection (ecology) and training local wardens. Developing effective conservation recommendations is the priority. 